\title{
Beata Altkorn
}

Instytut Nafty i Gazu - Państwowy Instytut Badawczy

\section{Siarka w bioetanolu - przyczyny rozbieżności wyników oznaczenia zawartości techniką fluorescencji UV i ICP-OES}

\begin{abstract}
Z praktyki laboratoryjnej INiG - PIB wynika, że w przypadku niektórych próbek handlowych bioetanoli, stosowanych jako biokomponent w benzynach silnikowych, oznaczenie zawartości siarki techniką ICP-OES oraz fluorescencji w nadfiolecie prowadzi do uzyskania wyników różniących się od siebie więcej niż o niepewność metody badania, zatem do wyników różnych. Rezultaty otrzymane techniką ICP-OES są wyższe od uzyskanych techniką fluorescencji UV. Przeprowadzono analizę przyczyn występowania tego zjawiska, biorąc pod uwagę rodzaj i ilość obecnych w bioetanolu związków siarki oraz źródła ich pochodzenia. Porównano metody i techniki analityczne stosowane w Europie i USA do oznaczania zawartości siarki w bioetanolu. Stwierdzono, że prawdopodobną przyczyną występowania różnic w poziomie zawartości siarki oznaczonej techniką fluorescencji w nadfiolecie i ICP-OES jest niewłaściwie dobrana substancja wzorcowa w metodyce EN 15837 (technika ICP-OES), co powoduje zawyżenie wyników. Drugą przyczyną jest jednoczesna obecność w bioetanolu siarki w postaci związków organicznych (np. siarczków i/lub heterocyklicznych związków aromatycznych zawierających atom siarki) i nieorganicznych - siarczanów. Zmiana substancji wzorcowej w technice ICP-OES z nieorganicznych jonów siarczanowych na heterocykliczny związek siarki, np. dibenzotiofen lub tionaften, pozwoliłaby prawdopodobnie na otrzymanie miarodajnych, poprawnych wyników analitycznych przy oznaczaniu zawartości siarki, występującej w bioetanolu głównie w postaci siarczków.
\end{abstract}

Słowa kluczowe: bioetanol, związki siarki, ICP-OES, technika spaleniowa z detekcją UV, wzorzec analityczny, krzywa wzorcowa.

\section{Sulphur in bioethanol - causes of discrepancies in the determination when using UV fluorescence and ICP-OES techniques}

From the laboratory practice of the Oil and Gas Institute - National Research Institute, it follows that for some commercial samples of bioethanol (fuel ethanol), determination of the sulfur content using for ICP-OES and UV fluorescence leads to results that differ from each other by more than the uncertainty of the test method, therefore different results. The results obtained for ICP-OES are higher when compared to fluorescence UV technique. An analysis of the causes of this phenomenon was carried out, taking into account the type and the amount of sulfur compounds present in the bioethanol and their source of origin. Methods and analytical techniques used in Europe and USA for the determination of the sulfur content in bioethanol were compared. It was found, that the probable cause of the differences in the level of sulfur content, determined by technique UV and ICP-OES is the improperly chosen reference substance in the methodology EN 15837 (technique ICP-OES), which tends to bias the results. The second reason is the simultaneous presence of sulfur in the bioethanol as organic sulfur compounds (eg. sulfide and/or heterocyclic aromatic compounds containing sulfur) and inorganic compounds - sulphates. Changing the standard substance in technique ICP-OES from inorganic sulphate ions to heterocyclic sulfur compound, for example dibenzothiophene or thionaphthene, would probably allow to obtain reliable analytical results for the determination of sulfur present in bioethanol, occurring in bioethanol mainly in the form of sulfides.

Key words: bioethanol, sulfur compounds, ICP-OES, combustion with UV detection, analytical standard, calibration curve.

\section{Wprowadzenie}

Bioetanol to alkohol etylowy o zawartości etanolu nie mniejszej niż 98\%, który otrzymuje się w wyniku fermentacji biomasy i stosuje jako biokomponent $\mathrm{w}$ benzynie silnikowej.
Aż do 2007 roku, kiedy to ustanowiono normę europejską EN 15376 [20], zawierającą wymagania dla bioetanolu stosowanego jako biokomponent $\mathrm{w}$ benzynie silnikowej, polska 
specyfikacja normatywna dla bioetanolu nie obejmowała zawartości siarki. W 2007 roku norma europejska (i ustanowiony w 2010 roku jej polski odpowiednik PN-EN 15376:2010) wprowadziła limit zawartości siarki na poziomie $10,0 \mathrm{mg} / \mathrm{kg}$ oraz dwie metodyki oznaczania zawartości siarki w bioetanolu - techniką fluorescencji w nadfiolecie oraz techniką rentgenowskiej spektrometrii fluorescencyjnej z dyspersją długości fali WD-XRF.

Kolejne edycje europejskiej specyfikacji normatywnej dla bioetanolu ustanawiano w latach 2009, 2011, 2012 i 2014, kiedy to do normy wprowadzono kolejną metodykę oznaczania zawartości siarki - techniką ICP-OES (spektrometrii emisji optycznej ze wzbudzeniem w plaźmie indukcyjnie sprzężonej).

Dopuszczalna zawartość siarki pozostała bez zmian w stosunku do pierwszego wydania normy, ale nastąpiła zmiana w samej technologii produkcji bioetanolu. Obok bioetanolu otrzymywanego klasycznie w drodze fermentacji ziarna, czyli tzw. bioetanolu I generacji, istnieje również bioetanol II generacji, uzyskiwany z lignocelulozy, charakteryzujący się zawartością siarki ogólnej o rząd wielkości niższą niż bioetanol I generacji, tj. około $1 \mathrm{mg} / \mathrm{kg}$.

Z doświadczenia Zakładu Analiz Naftowych INiG - PIB, jako akredytowanego laboratorium wykonującego oznaczenie zawartości siarki w bioetanolu, wynika, że zdarzają się próbki bioetanoli, w których oznaczenie zawartości siarki techniką ICP-OES oraz techniką fluorescencji w UV prowadzi do uzyskania wyników różniących się od siebie więcej niż o niepewność metody badania, czyli do wyników różnych. Niniejszy artykuł jest próbą wyjaśnienia przyczyn tego zjawiska.

\section{Rozeznanie przyczyn rozbieżności wyników oznaczenia zawartości siarki w bioetanolu różnymi technikami analitycznymi}

Norma PN-EN 15376:2016 [20], wprowadzająca normę europejską EN 15376:2014, określa trzy metodyki oznaczania zawartości siarki całkowitej w etanolu jako komponencie benzyn silnikowych (,,paliwowym”) właściwe do tego celu:

- rentgenowską spektrometrię fluorescencyjną z dyspersją długości fali WD-XRF - według EN 15485 [21],

- technikę fluorescencji w nadfiolecie - według EN 15486 [22],

- $\quad$ spektrometrię emisji optycznej ze wzbudzeniem w plaźmie indukcyjnie sprzężonej ICP-OES - według EN 15837 [23].

W przypadkach spornych dotyczących zawartości siarki należy posługiwać się techniką ICP-OES. Dodatkowo, oprócz zawartości siarki (całkowitej), w bioetanolu oznacza się rów- nież odrębnie zawartość nieorganicznych związków siarki, jakimi są siarczany nieorganiczne. Siarczany te oddziałują silnie korozyjnie na metale w układzie zasilania paliwem zawierającym bioetanol, nawet w bardzo niskim stężeniu (dodatkowo są promotorami powstawania osadów na wtryskiwaczach), stąd istnieje konieczność ograniczenia ich zawartości.

W tablicy 1 pokazano przykładowe wyniki oznaczenia zawartości siarki i siarczanów w handlowych próbkach bioetanolu, wykonywanych w laboratorium w latach 2015-2016. Niewątpliwe, istniejące rozbieżności w wynikach prawidłowo wykonanych oznaczeń wymagają analizy i próby wyjaśnienia przyczyny ich powstawania.

Tablica 1. Zestawienie różnic w wynikach oznaczenia zawartości siarki w próbkach handlowego bioetanolu techniką fluorescencji w nadfiolecie oraz techniką ICP-OES

\begin{tabular}{|l|c|c|c|c|c|}
\hline \multirow{2}{*}{$\begin{array}{l}\text { Technika } \\
\text { oznaczenia } \\
\text { siarki Nr próbki }\end{array}$} & $\mathrm{A}$ & $\mathrm{B}$ & $\mathrm{C}$ & $\mathrm{D}$ & E \\
\cline { 2 - 6 } & poniżej 2,0 & $3,9 \pm 0,5$ & $4,9 \pm 0,6$ & poniżej 2,0 & $3,8 \pm 0,5$ \\
\hline ICP-OES & poniżej 0,61 & $2,5 \pm 0,5$ & $2,1 \pm 0,4$ & poniżej 0,61 & $2,5 \pm 0,5$ \\
\hline Spalenie + detekcja UV & 0,51 & 0,48 & 0,8 & 0,17 & 0,63 \\
\hline Zawartość siarczanów $[\mathrm{mg} / \mathrm{kg}]$ & & & & \\
\hline
\end{tabular}

\section{Pochodzenie siarki w bioetanolu}

Żeby wyjaśnić tę kwestię, należy ustalić źródło i postać związków siarki w bioetanolu. Na rysunku 1 przedstawiono schemat produkcji bioetanolu. Jak widać, prekursory związków siarki i związki siarki w bioetanolu mogą pochodzić z pięciu źródeł $[4,8,9,11]$ :

- z surowca (biomasy),
- $\mathrm{z}$ wody - stosowanej w procesie technologicznym,

- $z$ drożdży - wykorzystywanych w procesie fermentacji,

- $\mathrm{z}$ chemikaliów - stosowanych w procesie produkcji bioetanolu,

- ze skażalnika.

Bioetanol może zawierać zarówno organiczne, jak i nie- 


\begin{tabular}{|c|c|}
\hline $\begin{array}{c}\text { Prekursory związów siarki zawarte } \\
\text { w surowcu (aminokwasy, siarczki) }\end{array}$ & Mycie i oczyszczanie surowca \\
\hline $\begin{array}{l}\text { Woda / zwiazki siarki zawarte } \\
\text { w wodzie }\end{array}$ & $\begin{array}{l}\text { Rozdrabnianie/parowanie surowca, } \\
\text { rozpuszczanie skrobi w wodzie }\end{array}$ \\
\hline & Hydroliza skrobi, tzw. zacieranie \\
\hline $\begin{array}{l}\text { Prekursory związów siarki } \\
\text { zawarte } w \text { drożdżach }\end{array}$ & Fermentacja zacieru \\
\hline \multirow{3}{*}{$\begin{array}{l}\text { Kwas siarkowy używany do } \\
\text { regulacji pH podczas procesu } \\
\text { fermentacji } \\
>\quad \text { Wodorosiarczyn sodu }\end{array}$} & Destylacja \\
\hline & | \\
\hline & Rektyfikacja \\
\hline Siarka ze skażalnika & Skażanie skażalnikiem \\
\hline $\begin{array}{c}\text { Sumaryczna zawartość siarki, } \\
\text { w tym siarka organiczna i siarka } \\
\text { nieorganiczna z siarczanów }\end{array}$ & Bioetanol „paliwowy” skażony \\
\hline
\end{tabular}
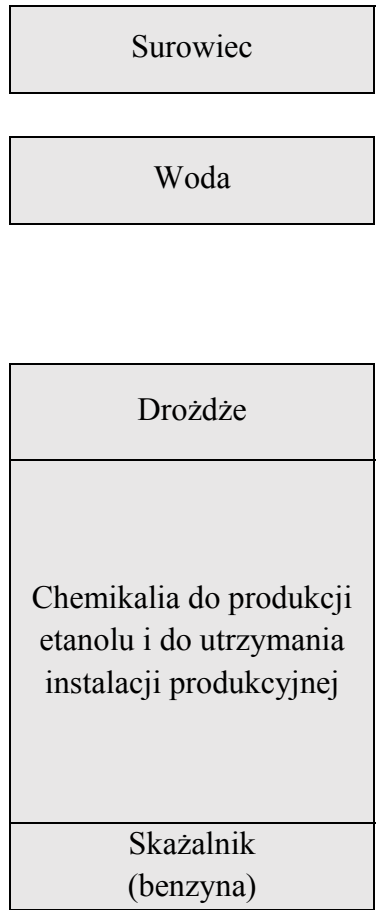

Rys. 1. Etapy produkcji bioetanolu stosowanego jako komponent paliw silnikowych

organiczne związki siarki. Organiczne związki siarki pochodzą z surowca (ziarno zawiera około $0,12 \div 0,2 \%$ siarki) i drożdży (aminokwasy zawierające siarkę w cząsteczce - cysteina i metionina, białka, siarczki, merkaptany), natomiast nieorganiczne $-z$ wody $i$ chemikaliów wykorzystywanych w procesie produkcji bioetanolu [2, 11, 12, 14]. Źródłem związków siarki mogą być zatem:

- woda - stosowana w parowaniu i hydrolizie skrobi z ziarna;

- kwas siarkowy - będący największym źródłem siarki nieorganicznej, nie występującej naturalnie w bioetanolu. Stosowany jest do regulacji $\mathrm{pH}$ w celu optymalizacji warunków fermentacji oraz podaje się go w sposób ciągły do kolumny destylacyjnej w celu zapobiegania i zmniejszenia tworzenia się osadów nierozpuszczalnych soli metaloorganicznych na powierzchni kolumny (szczawianu wapniowego, fitynianu wapnia/magnezu), pogarszających przenoszenie ciepła w kolumnie;

- kwas amidosulfonowy - wykorzystywany jako środek czyszczący do usuwania mineralnych osadów w wymiennikach ciepła na instalacji;

- wodorosiarczan(IV) sodowy - stosowany do usuwania aldehydu octowego z absorbera ditlenku węgla.

Należy również pamiętać, że bioetanol jest skażany. W przypadku bioetanolu dodawanego do benzyn silnikowych jest to „mieszanina benzyny silnikowej $3000 \mathrm{ml}$, eteru etylo-tert-butylowego (ETBE) $2000 \mathrm{ml}$ i alkoholu izopropylowego $1000 \mathrm{ml}$ w ilości minimalnej na $1 \mathrm{hl}$ alkoholu 100\%, w przypadku produkcji biopaliw klasyfikowanych do podklasy PKD 20.14.Z lub PKD 20.59.Z, w zależności od składu procentowego wyrobów" [24]. Skażalnik taki również wprowadza pewną niewielką, dodatkową ilość związków siarki do bioetanolu.

\section{Porównanie metod badań stosowanych w oznaczaniu zawartości siarki w bioetanolu}

Zgodnie ze specyfikacją PN-EN 15376:2016 w bioetanolu (polska normalizacja posługuje się terminem etanol jako komponent benzyny silnikowej dla określenia bioetanolu) do oznaczania zawartości siarki (jak należy domniemywać - całkowitej zawartości siarki) należy stosować następujące metody badań:
- PN-EN 15485:2009 Etanol jako komponent benzyny silnikowej. Oznaczanie zawartości siarki. Rentgenowska spektrometria fluorescencyjna z dyspersja fali,

- PN-EN 15486:2009 Etanol jako komponent benzyny silnikowej. Oznaczanie zawartości siarki. Metoda fluorescencji w nadfiolecie, 
- PN-EN 15837:2011 Etanol jako komponent benzyny silnikowej. Oznaczanie zawartości fosforu, miedzi i siarki. Metoda bezpośrednia z zastosowaniem optycznej spektrometrii emisyjnej indukcyjnie sprzężonej plazmy (ICP-OES). Normy EN 15485 oraz EN 15486 wprowadzają techniki analityczne powszechnie stosowane do oznaczania zawartości siarki w węglowodorach, ale na potrzeby ich wykorzystania w badaniu bioetanolu ustanowiono odrębne edy- cje norm. Norma EN 15837 została natomiast opracowana specjalnie na potrzeby analityki bioetanolu i nie ma swojego odpowiednika w badaniu węglowodorów (pozwala ona w toku jednego badania oznaczyć jednocześnie - obok siarki - zawartość fosforu i miedzi).

Oprócz metodyk i technik oznaczania zawartości siarki wskazanych w europejskiej specyfikacji etanolu jako komponentu benzyny silnikowej EN 15376 - w praktyce laboratoryjnej

Tablica 2. Porównanie rodzajów metodyk badań dla bioetanolu i węglowodorów w zakresie metod analitycznych stosowanych w oznaczaniu siarki wymienionych w europejskiej [20] i amerykańskiej [17] specyfikacji dla bioetanolu

\begin{tabular}{|c|c|c|c|c|}
\hline Metoda analityczna & $\begin{array}{l}\text { Metoda rentgenowskiej } \\
\text { spektrometrii fluore- } \\
\text { scencyjnej z dyspersją } \\
\text { długości fali WD-XRF }\end{array}$ & $\begin{array}{c}\text { Metoda spaleniowa } \\
\mathrm{z} \text { detekcją techniką } \\
\text { fluorescencji w nad- } \\
\text { fiolecie }\end{array}$ & $\begin{array}{l}\text { Metoda bezpośrednia z zasto- } \\
\text { sowaniem spektrometrii emisji } \\
\text { optycznej ze wzbudzeniem } \\
\text { w plaźmie indukcyjnie sprzężo- } \\
\text { nej (ICP-OES) }\end{array}$ & $\begin{array}{l}\text { Metoda } \\
\text { mikrokulometrii } \\
\text { oksydacyjnej }\end{array}$ \\
\hline $\begin{array}{l}\text { Metodyki znormalizowane } \\
\text { specyficzne tylko dla bio- } \\
\text { etanolu }\end{array}$ & EN 15485 & EN 15486 & EN 15837 & - \\
\hline \multirow{5}{*}{$\begin{array}{l}\text { Metodyki znormalizowane } \\
\text { wspólne dla węglowodorów } \\
\text { i bioetanolu }\end{array}$} & EN ISO 14596 & EN ISO 20846 & \multirow{5}{*}{-} & \multirow{5}{*}{ ASTM D 3120} \\
\hline & EN ISO 20884 & EN 15486 & & \\
\hline & EN ISO 8754 & \multirow{3}{*}{ ASTM D 5453} & & \\
\hline & ASTM D 2622 & & & \\
\hline & ASTM D 7039 & & & \\
\hline
\end{tabular}

Tablica 3. Porównanie europejskich obligatoryjnych metod oznaczania zawartości siarki w bioetanolu

\begin{tabular}{|c|c|c|c|}
\hline Norma & PN-EN 15485:2009 & PN-EN 15486:2009 & PN-EN 15837:2011 \\
\hline Technika analityczna & $\begin{array}{c}\text { rentgenowska spektrometria } \\
\text { fluorescencyjna } \mathrm{z} \text { dyspersją } \\
\text { długości fali }\end{array}$ & $\begin{array}{c}\text { metoda spaleniowa } \mathrm{z} \text { detekcją } \\
\text { techniką fluorescencji } \\
\text { w nadfiolecie }\end{array}$ & $\begin{array}{l}\text { metoda bezpośrednia z zasto- } \\
\text { sowaniem spektrometrii emisji } \\
\text { optycznej ze wzbudzeniem } \\
\text { w plaźmie indukcyjnie sprzężo- } \\
\text { nej (ICP-OES) }\end{array}$ \\
\hline $\begin{array}{l}\text { Granica stosowalności } \\
\text { znormalizowanej metody }\end{array}$ & $7 \mathrm{mg} \mathrm{S} / \mathrm{kg}$ & $5 \mathrm{mg} \mathrm{S} / \mathrm{kg}$ & $2,0 \mathrm{mg} \mathrm{S} / \mathrm{kg}$ \\
\hline \multirow{3}{*}{ Wzorzec } & siarczek dibutylu & siarczek dibutylu & \multirow{3}{*}{$\begin{array}{l}\text { wodorosiarczan(VI) tetrabuty- } \\
\text { loamonowy lub wodne podsta- } \\
\text { wowe roztwory wzorcowe }\end{array}$} \\
\hline & \multirow{2}{*}{ disiarczek dibutylu } & dibenzotiofen & \\
\hline & & tionaften (benzotiofen) & \\
\hline $\begin{array}{l}\text { Właściwości substancji } \\
\text { wzorcowej }\end{array}$ & \multicolumn{2}{|c|}{$\begin{array}{l}\text { substancje bardzo lotne, należy zachować ostrożność } \\
\text { podczas naważania }\end{array}$} & nielotny \\
\hline $\begin{array}{l}\text { Rozpuszczalnik do sporzą- } \\
\text { dzania roztworów podsta- } \\
\text { wowych/wzorcowych }\end{array}$ & $\begin{array}{l}\text { etanol absolutny } 99 \% \text { o zawarto- } \\
\text { ści siarki } 1 \mathrm{mg} / \mathrm{kg} \text { (sygnał siarki } \\
\text { musi być niewykrywany na XRF) }\end{array}$ & $\begin{array}{l}\text { etanol o czystości odczynniko- } \\
\text { wej / opcjonalnie toluen, } \\
\text { o znanej zawartości siarki }\end{array}$ & $\begin{array}{l}\text { etanol o czystości co najmniej } \\
99 \%\end{array}$ \\
\hline $\begin{array}{l}\text { Roztwory podstawowe do } \\
\text { roztworów wzorcowych }\end{array}$ & $\begin{array}{l}\text { stabilne przez dłuższy czas, brak } \\
\text { informacji o warunkach przecho- } \\
\text { wywania }\end{array}$ & $\begin{array}{l}\text { stabilne przez } 3 \text { miesiące, } \\
\text { przechowywać w chłodziarce }\end{array}$ & handlowe, trwałe \\
\hline Roztwory wzorcowe & $\begin{array}{l}\text { mało stabilne, należy zużyć } \\
\text { w dniu sporządzenia }\end{array}$ & $\begin{array}{l}\text { stabilne przez } 1 \text { miesiąc lub } \\
\text { krócej, w chłodziarce }\end{array}$ & $\begin{array}{l}\text { należy sporządzać bezpośred- } \\
\text { nio przed każdą serią pomiarów }\end{array}$ \\
\hline Kontrola jakości pomiarów & tak & tak & $\begin{array}{l}\text { próbka QC do kontroli jakości, } \\
\text { świeżo sporządzana dla każdej } \\
\text { serii pomiarów }\end{array}$ \\
\hline $\begin{array}{l}\text { Uwzględnienie zawartości } \\
\text { wody w etanolu w oblicze- } \\
\text { niu zawartości siarki }\end{array}$ & nie & tak & tak \\
\hline
\end{tabular}


stosuje się w świecie z powodzeniem również inne, np. w normatywnej specyfikacji amerykańskiej ASTM D 4806-16a [17] dla bioetanolu jako właściwe wskazane są trzy techniki (a cztery znormalizowane metodyki dla oznaczania siarki):

- rentgenowska spektrometria fluorescencyjna z dyspersją długości fali WD-XRF - wg ASTM D 2622 oraz ASTM D 7039 [15, 19],

- fluorescencja w nadfiolecie - wg ASTM D 5453 [18],

- mikrokulometria oksydacyjna - wg ASTM D 3120 [16].

Pierwsze dwie techniki analityczne pokrywają się z technikami wskazanymi do oznaczania zawartości siarki w analogicznej normatywnej specyfikacji europejskiej [20]. Amerykanie stosują do tego celu wprost - lub po modyfikacji - te same normy, co do oznaczania zawartości siarki w węglowodorowych produktach naftowych. Żadna z powyższych norm czynnościowych, nawet w tytule, nie zawiera odniesienia, że jest przeznaczona do oznaczania siarki w bioetanolu. Normalizacja amerykańska nie dysponuje metodą oznaczania siarki w bioetanolu metodą ICP-OES.

Porównanie metodyk w zakresie oznaczania siarki w bioetanolu i węglowodorach przedstawiono w tablicy 2 [6].

W tablicy 3 zestawiono najważniejsze cechy wszystkich trzech metod oznaczania zawartości siarki wskazanych w europejskiej specyfikacji dla bioetanolu, które potencjalnie mogą mieć wpływ na różnice w otrzymywanych wynikach oznaczeń.

\section{Charakterystyka europejskich metod oznaczania zawartości siarki w bioetanolu}

Metoda fluorescencji $w$ nadfiolecie polega na spaleniu próbki w piecu w atmosferze tlenu, w temperaturze około $1000^{\circ} \mathrm{C}$, i utlenieniu zawartych w próbce związków siarki do $\mathrm{SO}_{2}$. Po usunięciu wody i innych zanieczyszczeń próbka przepływa z pieca do komory pomiarowej, gdzie promieniowanie ultrafioletowe powoduje wzbudzenie cząsteczek $\mathrm{SO}_{2}$. Podczas powrotu wzbudzonych cząsteczek $\mathrm{SO}_{2}$ do stanu podstawowego emitowane jest promieniowanie UV, proporcjonalne do stężenia $\mathrm{SO}_{2}$, które jest miarą całkowitej zawartości siarki w próbce (nie jest to metoda pomiaru bezpośredniego). Całkowitą zawartość siarki w badanej próbce oblicza się na podstawie sporządzonej wcześniej krzywej wzorcowej.

Metoda rentgenowskiej spektrometrii fluorescencyjnej $z$ dyspersja dtugości fali WD-XRF polega na poddaniu badanej próbki, umieszczonej w kuwecie pomiarowej, działaniu pierwotnego promieniowania lampy rentgenowskiej. Pod jego wpływem emitowane jest charakterystyczne promieniowanie rentgenowskie. W metodzie mierzy się intensywność (szybkość zliczeń impulsów) rentgenowskiego promieniowania fluorescencyjnego linii $\mathrm{K} \alpha \mathrm{w}$ porównaniu do promieniowania tła (nie jest to metoda pomiaru bezpośredniego). Zawartość siarki w próbce oblicza się na podstawie przygotowanej wcześniej krzywej wzorcowej.

Metoda spektrometrii emisji optycznej ze wzbudzeniem w plaźmie indukcyjnie sprzężonej ICP-OES polega na wprowadzeniu próbki bioetanolu bezpośrednio do komory mgielnej spektrometru ICP-OES. Zawartość siarki wyznacza się przez porównanie emisji siarki w próbce analitycznej z emisją w roztworach wzorcowych przy tej samej długości fali. Roz- twory wzorcowe przygotowuje się z odpowiednich składników rozpuszczonych w etanolu lub wykorzystuje się dostępne handlowo roztwory podstawowe siarki (związki siarki muszą być rozpuszczalne w etanolu, w laboratorium INiG - PIB stosuje się do tego celu wodny roztwór kwasu siarkowego). Wzorcowanie przeprowadza się metodą serii roztworów wzorcowych.

Pomimo że specyfikacja europejska dopuszcza zawartość siarki w bioetanolu do poziomu $10 \mathrm{mg} / \mathrm{kg}$, w rzeczywistości zawartość ta w handlowych próbkach jest znacznie mniejsza - na poziomie niższym niż granica stosowalności normy PN-EN 15486:2009 (metoda fluorescencji w nadfiolecie), tj. $5 \mathrm{mg} \mathrm{S} / \mathrm{kg}$, a tym samym niższym niż granica stosowalności normy PN-EN 15485:2009 metody WD-XRF, wynosząca $7 \mathrm{mg} \mathrm{S} / \mathrm{kg}$. Dlatego też przedmiotem prac prowadzonych w 2010 roku w Zakładzie Analiz Naftowych INiG - PIB było rozszerzenie zakresu stosowalności i walidacja w tym zakresie metody oznaczania zawartości siarki w bioetanolu służącym jako komponent paliw silnikowych techniką fluorescencji w nadfiolecie według PN-EN 15486:2009. Z uwagi na niską zawartość siarki w badanych próbkach bioetanolu, dostarczanych przez producentów oraz dostępnych na rynku, zakres stosowalności wdrażanej metody rozszerzono w kierunku niższych wartości, jednocześnie określając granicę wykrywalności i oznaczalności metody. Wyznaczono granicę oznaczalności siarki, wynoszącą $0,61 \mathrm{mg} / \mathrm{kg}$ siarki, i zwalidowano metodę w zakresie stężeń siarki $0,61 \div 5,0 \mathrm{mg} / \mathrm{kg}$ [7]. Nie wykonano takiej walidacji dla metody WD-XRF, stąd w laboratorium nie stosuje się jej w badaniu bioetanolu.

\section{Związki siarki występujące w bioetanolu}

W praktyce w spirytusie rektyfikowanym, jakim jest bioetanol, nie występuje aż taka różnorodność organicznych związków siarki jak w benzynie czy oleju napędowym. W literaturze, o ile dużo jest pozycji dotyczących zawartości 
związków siarki w winie, piwie i innych wyrobach przemysłu spirytusowego, to w zakresie bioetanolu dostępność informacji jest raczej niewielka.

Według jednych badań wódki czyste, najbardziej składem związków siarki zbliżone do bioetanolu, nie zawierają disiarczku dimetylu w ilościach powyżej zakresu oznaczalności metody [2].

Według innych informacji w czystych wódkach polskich, fińskich i rosyjskich, analizowanych techniką spektrometrii mas, stwierdzono występowanie disiarczku dimetylu w stężeniu między 0,2 a 2,0 $\mu \mathrm{g} / 1$, natomiast stężenie siarczku dimetylu, trisiarczku dimetylu i siarczanu dietylu było poniżej granicy oznaczalności metody [8].

Z kolei w 26 próbkach różnych polskich spirytusów rolniczych z lokalnych destylarni (o zawartości powyżej 90\% etanolu) techniką HS-SPME ${ }^{1}$ GC-MS badano m.in. zawartość organicznych związków siarki i stwierdzono obecność [9]:

- trisiarczku dimetylu,

- 2-pentylotiofenu,

- disiarczku metylowo-furfurylowego,

- 2-metylo-tieno[2,3-b]tiofenu.

Generalnie można stwierdzić, że w bioetanolu występują różne związki organiczne siarki oraz siarczany nieorganiczne.
Przemysł spirytusowy stosuje inne metody badania spirytusu rektyfikowanego niż przemysł paliwowy [1]. W wyrobach spirytusowych oznacza się praktycznie wyłącznie zawartość $\mathrm{SO}_{2}$, natomiast oznaczanie poszczególnych związków siarki i obliczenie na tej postawie całkowitej zawartości siarki przeprowadza się metodą chromatografii gazowej z detektorem czułym na siarkę, głównie PFPD, lub detektorem FID. Badania te wykonuje się w celu określenia zawartości substancji zapachowych oraz zidentyfikowania pochodzenia wyrobu (tzw. fingerprint lub aromafingerprint).

Według materiałów firmy RESTEC, producenta chromatografów gazowych, poszczególne związki siarki w wyrobach alkoholowych występują w stężeniach rzędu ppb lub ppm. W związku z powyższym, zarówno chromatografy przeznaczone do oznaczania związków siarki w etanolu, jak i pojemniki na próbki powinny być wykładane powłoką z Sulfinertu, który - w przeciwieństwie do powierzchni stalowych w aparacie - nie wchodzi w reakcję ze związkami siarki oraz nie posiada ,pamięci” siarki, jaką mogą wykazywać pojemniki na próbki wytworzone z polimerów. Oznacza się zawartość poszczególnych związków siarki, np. siarkowodoru, merkaptanu metylowego, dimetylosiarczku, merkaptanu etylowego. Zawartość siarki całkowitej nie jest tu istotna, dlatego też nie oznacza się jej $[5,10]$.

\section{Wyniki międzylaboratoryjnych badań porównawczych oznaczania zawartości siarki w etanolu ,paliwowym" $[3,4,13]$}

Institute for Interlaboratory Studies w Holandii od 2013 roku organizuje porównania międzylaboratoryjne PT (proficiency test) kompetencji laboratoriów w zakresie badania parametrów jakościowych bioetanolu (etanolu ,paliwowego"), w tym zawartości siarki. Uczestniczą w nich laboratoria z całego świata, stosujące różne techniki badań i różne znormalizowane procedury. W celu stwierdzenia, czy w badaniach porównawczych widoczne są różnice w oznaczonej zawartości siarki w zależności od zastosowanej techniki badawczej, w tablicy 4 zestawiono rezultaty badań międzylaboratoryjnych. Niestety, z analizy uzyskanych rezultatów porównań można wnioskować, że zawartość siarki w badanych

Tablica 4. Wyniki porównań międzylaboratoryjnych organizowanych przez Institute for International Studies dotyczące oznaczania zawartości siarki w etanolu ,paliwowym” $[3,4,13]$

\begin{tabular}{|l|c|c|c|}
\hline \multicolumn{1}{|c|}{ Rok dokonania porównań międzylaboratoryjnych } & 2013 & 2014 & 2015 \\
\hline Symbol porównań & iis13C12 revised & iis15C10 & iis15C14 \\
\hline Oznaczona średnia zawartość siarki $[\mathrm{mg} / \mathrm{kg}]$ & 1,8 & 0,83 & 0,459 \\
\hline Liczba uczestników & 43 & 29 & 29 \\
\hline Liczba uczestników stosujących technikę badania: WD-XRF & 15 & 8 & 7 \\
\hline UV: & & 9 & 10 \\
- EN 15486 & 19 & 16 & 27 \\
- ASTM D 5453 & 0 & 0 & 0 \\
\hline ICP-OES & brak & brak & brak \\
\hline Możliwość wyciągnięcia wniosków & & & \\
\hline
\end{tabular}

\footnotetext{
${ }^{1} \mathrm{HS}-\mathrm{SPME}$ - mikroekstrakcja do fazy stacjonarnej z fazy nadpowierzchniowej.
} 
próbkach bioetanolu była niewłaściwie dobrana - zbyt niska, aby uzyskać wynik w zakresie stosowalności danej metodyki oznaczania (za wyjątkiem normy ASTM D 5433, która ma zakres stosowalności od zawartości siarki wynoszącej $1 \mathrm{mg} / \mathrm{kg}$ ), stąd ani wyników, ani wyników obliczeń statystycznych nie można uznać za w pełni miarodajne.

Żadne z uczestniczących laboratoriów przez 3 lata nie zastosowało techniki ICP-OES, posługując się innymi techni- kami, bardziej im znanymi z doświadczeń w analityce produktów naftowych, pomimo że normę EN 15837 [23] ustanowiono już w 2009 roku. Mało które laboratorium w świecie posługuje się zatem metodyką wskazaną w specyfikacji europejskiej bioetanolu jako właściwą w przypadkach spornych odnośnie do zawartości siarki, stąd brak jest obserwacji odnośnie do różnic w wynikach uzyskiwanych tą metodą i techniką fluorescencji w nadfiolecie.

\section{Podsumowanie}

Prawdopodobną przyczyną rozbieżności pomiędzy wynikami oznaczenia zawartości siarki techniką fluorescencji w nadfiolecie i metodą ICP-OES jest:

- nieodpowiedni dobór substancji wzorcowej w technice ICP-OES do oznaczania siarki - w postaci związków organicznych,

- jednoczesna obecność w próbce siarki w postaci związków organicznych (np. siarczków i/lub heterocyklicznych związków aromatycznych zawierających atom siar-

ki) i związków nieorganicznych - siarczanów.

Podstawą do zrozumienia różnic w uzyskiwanych wynikach analitycznych jest proces pomiaru sygnału analitycznego. W przypadku techniki fluorescencji w UV - źródłem sygnału analitycznego są cząsteczki $\mathrm{SO}_{2}$, powstałe w wyniku spalania organicznych związków siarki w tlenie. W technice ICP-OES źródłem sygnału analitycznego są natomiast atomy siarki powstające w plazmie - zarówno ze związków organicznych siarki, jak i siarczanów. Należy podkreślić, że do wytworzenia atomów siarki z siarczków nie jest potrzebna tak wysoka energia jak do ich utworzenia z siarczanów. Z tego względu zastosowanie siarczanów jako substancji wzorcowych (do wygenerowania krzywej wzorcowej) do techniki analitycznej ICP-OES prowadzi do wystąpienia błędu systematycznego oznaczeń w przypadku obecności w badanej próbce bioetanolu siarczków i innych organicznych związków siarki. Błąd ten polega na zawyżeniu uzyskanego wyniku oznaczania. Aby go wyeliminować, należałoby w metodzie ICP-OES odpowiednio zastosować organiczne związki siar- ki jako substancje wzorcowe do sporządzenia krzywej wzorcowej, np. jeden z zalecanych w normie PN-EN 15486:2009 (technika fluorescencji w UV) związków wzorcowych siarki: siarczek dibutylu, dibenzotiofen lub tionaften (benzotiofen).

W przypadku bioetanolu, w którym jednocześnie występują związki siarki w postaci siarczków i siarczanów (a ten przypadek zachodzi w przypadku bioetanolu I generacji), aby uzyskać prawidłowy wynik oznaczenia techniką ICP-OES, we wzorcowaniu należałoby uwzględnić odpowiednie proporcje stężenia siarczków i siarczanów. Potwierdzenie tej tezy wymaga jednak przeprowadzenia szeroko zakrojonych badań, które nie były przedmiotem niniejszej pracy.

Powszechne stosowanie aparatu do metody fluorescencji w nadfiolecie w laboratoriach wykonujących badania jakościowe bioetanolu do celów paliwowych, wynikające z faktu wcześniejszego ustanowienia norm wykorzystujących tę technikę do oznaczania siarki w bioetanolu, skutkuje praktycznym brakiem wykorzystania metody ICP-OES do tego celu (na co wskazują wyniki międzynarodowych porównań międzylaboratoryjnych IIS z lat 2013-2015 [3, 4, 13]). Na przykład, w Polsce akredytację na oznaczanie siarki w bioetanolu z zastosowaniem normy PN-EN 15837:2011 (technika ICP-OES) posiada wyłącznie Instytut Nafty i Gazu - Państwowy Instytut Badawczy. Z tego względu laboratoria nie mają możliwości porównania wyników uzyskanych techniką UV i techniką ICP-OES, zwłaszcza że zawartość siarki w próbkach jest poniżej wartości dopuszczalnej przez specyfikację dla etanolu stosowanego jako komponent benzyn silnikowych.

\section{Wnioski}

1. Na wynik oznaczenia siarki w bioetanolu wpływa zarówno siarka zawarta w siarczkach i innych związkach organicznych siarki, jak i w siarczanach nieorganicznych (większość siarki pochodzi ze związków organicznych).

2. Zmiana substancji wzorcowej w technice ICP-OES z nie- organicznych jonów siarczanowych na heterocykliczny związek siarki, np. dibenzotiofen lub tionaften, pozwoliłaby prawdopodobnie na otrzymanie miarodajnych wyników analitycznych przy oznaczaniu zawartości siarki, występującej w bioetanolu głównie w postaci siarczków.

Prosimy cytować jako: Nafta-Gaz 2017, nr 7, s. 510-517, DOI: 10.18668/NG.2017.07.09

Artykuł nadesłano do Redakcji 14.12.2016 r. Zatwierdzono do druku 24.03.2017 r. 
Artykuł powstał na podstawie pracy statutowej pt. Badania skłonności paliwa etanolowego E20-E25 do zanieczyszczenia elementów silnika testowego - praca INiG - PIB na zlecenie MNiSW; nr zlecenia 0046/TE/16/1.

\section{Literatura}

[1] Burnus Z., Jędrychowska S., Kopydłowski A., Wieczorek A.: Przeglad metod analitycznych stosowanych $w$ oznaczaniu właściwości bioetanolu. Nafta-Gaz 2011, nr 6, s. 410-416.

[2] Cardoso D.R., Andrade S., Luiz G., Lima-Neto B.S., Franco D.W.: A rapid and sensitive method for dimethylsulphide analysis in Brazilian sugar cane sugar spirits and other distilled beverages. Journal of the Brazilian Chemical Society 2004 , vol. 15 , no. 2 , s. $277-281$, DOI: $10.1590 / \mathrm{S} 0103-$ 50532004000200019 .

[3] Dijkstra L.: Results of Proficiency Test Fuel/Bio-ethanol, November 2013. Report iis13C12-revised, Institute for Interlaboratory Studies, March 2014, http://www.iisnl.com/ news_\&_report pagina.html (dostęp: 20.02.2017).

[4] Dijkstra L.: Results of Proficiency Test Fuel/Bio-ethanol, November 2015. Report iis14C10, Institute for Interlaboratory Studies, March 2015, http://www.iisnl.com/news_\&_report pagina.html (dostęp: 20.02.2017).

[5] Equistar Chemicals: Ethyl Alcohol Handbook. Pure Ethyl Alcohol, Specially Denatured Alcohol, Alcohol Solvents, Completely Denatured Alcohol. $6^{\text {th }}$ edition, 2003, http://www. industrilaethanol.com (dostęp: 20.02.2017).

[6] Ethanol guideline. From the Worldwide Fuel Charter Committee. First Edition, March 2009, http://www.autoalliance. org/auto-issues/fuels (dostęp: 20.02.2017).

[7] Jędrychowska S.: Oznaczanie zawartości siarki w bioetanolu slużacym jako komponent benzyn silnikowych. Nafta-Gaz 2010, nr 12, s. 1176-1182.

[8] Leppanen O., Denslow J., Ronkainen P.: A gas chromatographic method for the accurate determination of low concentration of volatile sulphur compound in alcoholic beverages. Journal of the Institute of Brewery 1979, vol. 85, s. 350-353.

[9] Plutowska B., Biernacka P., Wardencki W.: Identification of volatile compound in raw spirits of different organoleptic quality. Journal of the Institute of Brewing 2010, vol. 116, no. 4 , s. 433-439.

[10] Restec Corporation: Analyzing alcoholic beverages by gas chromatography. Technical Guide. 2002, https://www.restek. com/pdfs/59462.pdf (dostęp: 20.02.2017).

[11] Retka-Schill S.: Sulfur compounded in ethanol regulations. https://www.ethanolproducer.com/articles/13513/sulfurcompound-in-ethanol-regulation (dostęp: 15.07.2016).

[12] Slunecka T.: Protecting distillers grains from sulfur build-up. http://www.ethanolproducer.com/articles/5660/protectingdistillers-grains-from-sulfur-build-up (dostęp: maj 2009).

[13] Starink R.J.: Results of Proficiency Test Fuel/Bio-ethanol, December 2015. Report iis15C14, Institute for Interlaboratory Studies, February 2016, http://www.iisnl.com/pdf/iis15C14. pdf (dostęp: 20.02.2017).

[14] Zhang Y.: Sulfur Concentration in Distiller's Dried Grains with Soluble (DDGS) and Its Impact on Palatability and Pig
Performance - NPB \#08-093. National Corn-to-Ethanol Research Center 2010.

\section{Normy i przepisy prawne}

[15] Norma ASTM D 2622-16 Standard Test Method for Sulfur in Petroleum Products by Wavelength Dispersive X-ray Fluorescence Spectrometry.

[16] Norma ASTM D 3120-08(2014) Standard Test Method for Trace Quantities of Sulfur in Light Liquid Petroleum Hydrocarbons by Oxidative Microcoulometry.

[17] Norma ASTM D 4806-16a Standard Specification for Denatured Fuel Ethanol for Blending with Gasolines for Use as Automotive Spark-Ignition Engine Fuel.

[18] Norma ASTM D 5453-16e1 Standard Test Method for Determination of Total Sulfur in Light Hydrocarbons, Spark Ignition Engine Fuel, Diesel Engine Fuel, and Engine Oil by Ultraviolet Fluorescence.

[19] Norma ASTM D 7039-15a Standard Test Method for Sulfur in Gasoline, Diesel Fuel, Jet Fuel, Kerosine, Biodiesel, Biodiesel Blends, and Gasoline-Ethanol Blends by Monochromatic Wavelength Dispersive X-ray Fluorescence Spectrometry.

[20] Norma PN-EN 15376:2016 Paliwa do pojazdów samochodowych - Etanol jako komponent benzyny silnikowej - Wymagania i metody badań.

[21] Norma PN-EN 15485:2009 Etanol jako komponent benzyny silnikowej - Oznaczanie zawartości siarki - Rentgenowska spektrometria fluorescencyjna z dyspersja fali.

[22] Norma PN-EN 15486:2009 Etanol jako komponent benzyny silnikowej-Oznaczanie zawartości siarki - Metoda fluorescencji w nadfiolecie.

[23] Norma PN-EN 15837:2011 Etanol jako komponent benzyn silnikowych - Oznaczanie zawartości fosforu, miedzi i siarki-Metoda bezpośrednia z zastosowaniem optycznej spektrometrii emisyjnej indukcyjnie sprzężonej plazmy (ICP OES).

[24] Rozporządzenie Ministra Finansów z dnia 7 lipca 2016 r. zmieniające rozporządzenie w sprawie dokumentu dostawy, warunków i sposobu zwrotu wyrobów akcyzowych objętych zwolnieniem od akcyzy ze względu na ich przeznaczenie oraz środków skażających alkohol etylowy (Dz.U. z 2016 r. poz. 1028).

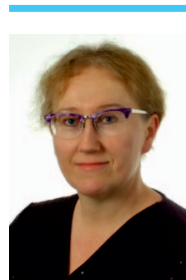

Dr inż. Beata ALTKORN

Adiunkt, kierownik Zakładu Analiz Naftowych. Instytut Nafty i Gazu - Państwowy Instytut Badawczy ul. Lubicz 25 A

31-503 Kraków

E-mail: beata.altkorn@inig.pl 